\title{
Perbandingan Metode Moving Average dan Metode Naïve Dalam Peramalan Data Kemiskinan
}

\author{
${ }^{1}$ Ais Kumila, ${ }^{2}$ Baqiyatus Sholihah, ${ }^{3}$ Evizia, ${ }^{4}$ Nur Safitri, ${ }^{5}$ Safama Fitri \\ 1,2,3,4,5Tadris Matematika, Universitas Islam Negeri Mataram, Indonesia \\ 17 170103001.mhs@uinmataram.ac.id, ${ }^{2}$ 170103002.mhs@uinmataram.ac.id, ${ }^{3}$ 170103046.mhs@uinmataram.ac.id, \\ 4170103003.mhs@uinmataram.ac.id, ${ }^{5}$ 170103029.mhs@uinmataram.ac.id
}

\begin{tabular}{l} 
INFO ARTIKEL \\
RiwayatArtikel: \\
Diterima: 20-03-2019 \\
Disetujui: 30-04-2019 \\
\hline
\end{tabular}

\section{Kata Kunci:}

Moving Average,

Metode Naive,

Time SeriesData,

Kemiskinan

Keywords:

Moving Average,

Naive Methode,

Time Series Data,

Poor People

\begin{abstract}
ABSTRAK
Abstrak: Penelitian ini bertujuan untuk memprediksi metode terbaik pada sistem peramalan dengan menggunakan metode Moving Average (SMA, WMA, dan EMA) dan metode Naive. Pada tahap simulasi, kami menggunakan data jumlah kemiskinan penduduk Provinsi Nusa Tenggara Barat (NTB) tahun 2002-2018 untuk memprediksi data tahun 2019. Adapun, model dievaluasi untuk melihat tingkat akurasi masing-masing metode berdasarkan nilai MAD, MSE, RMSE dan MAPE. Berdasarkan hasil simulasi data dari metode-metode yang diuji, diketahui bahwa metode Naive paling akurat dengan hasil prediksi tahun 2019 sebesar 737.460 dengan MAD, MSE, RMSE dan MAPE berturut-turut sebesar 41.427,188; 2.711.468.146; 52.071,760; dan 0.043.
\end{abstract}

\begin{abstract}
This study aims to predict the best method on the forecasting system using the Moving Average method (SMA, WMA, and EMA) and the Naive method. In the simulation phase, we used data on the Number of Poverty of the Population of West Nusa Tenggara (NTB) in 2002-2018 to predict the Poverty of Population of the Province of West Nusa Tenggara (NTB) in 2019. Meanwhile, the model was evaluated to see the accuracy of each method based on the value MAD, MSE, RMSE and MAPE. Based on the simulation results of the data from the methods tested, it can be seen that the Naive method is most accurate with the results of the 2019 prediction of 737,460 with MAD, MSE, RMSE and MAPE in the amount of 41.427,188; 2.711.468.146; 52.071,760; and 0.043.
\end{abstract}

\section{A. LATAR BELAKANG}

Peramalan (forecasting) adalah suatu kegiatan untuk mengetahui apa yang akan terjadi dimasa yang akan datang, dengan menggunakan data dari masa lampau. Peramalan juga digunakan sebagai alat bantu yang penting dalam sebuah perencanaan yang efektif. Dalam menghitung peramalan, hal yang terpenting adalah bagaimana cara kita memahami karakteristik suatu metode yang akan digunakan dalam peramalan tersebut agar sesuai dengan situasi pengambilan keputusan.
Dalam penelitian ini kami menggunakan metode Moving Average dan metode Naivekarena kedua metode ini adalah metode yang paling sering digunakan dan paling sederhana dalam menghitung peramalan (forecasting).

MetodeMoving Average merupakan metode peramalan yang dilakukan dengan mengambil sekelompok nilai pengamatanuntuk mencari nilai rata-rata tersebut sebagai ramalan periode yang akan datang. Metode ini disebut rata-rata bergerak karena setiap kali data observasi baru tersedia, maka angka rata-rata baru dihitung dan digunakan sebagai nilai ramalan. Teknik rata-rataMoving Average 
mempunyai karakteristik yaitu faktor penyebab yang berlaku di masa lalu dipakai pada masa yang akan datang, peramalan tidak pernah sempurna, permintaan aktual selalu berbeda dengan permintaan yang diramalkan, serta tingkat ketepatan ramalan akan berkurang dalam rentang waktu yang semakin panjang, peramalan untuk rentang waktu yang pendek lebih akurat dibandingkan dengan peramalan jangka panjang. (Hari Utari, et al, 2016: 1)

Umumnya peramalan banyak dilakukan pada data time series yang dikelola oleh Badan Pusat Statistika(BPS) baik kabupaten, provinsi, maupun nasional karena berdampak pada penentuan kebijakan oleh pemerintah(Lalu Sucipto, Syaharudin, 2018: 115)

Kesejahteraan masyarakat merupakan tujuan akhir dari proses pembangunan baik di pusat maupun di daerah. Meningkatnya kesejahteraan masyarakat di setiap daerah mengindikasikan bahwa ada peningkatan kualitas hidup masyarakat disuatu wilayah.Oleh karena itu, pemerintah berusaha menentukan kebijakan yang paling tepat untukmenanggulangi permasalahan-permasalahan yang terjadi di tengah masyarakat.

Peramalan adalah salah satu cara yang sering dijadikan sebagai patokan bagi pemerintah dalam membangun kebijakan selanjutnya. Salah satu kebijakan pemerintah yakni menangani kemiskinan yang dialami penduduk dengan mengetahui peramalan jumlah kemiskinan penduduk pada tahun mendatang.Hasil peramalan data kemiskinan penduduk ini diharapkan dapat memberikan masukan penting bagi pemerintah sebagai bahandalam pelaksanaan, perbaikan dan penyusunan kebijakan tentang kemiskinan pada periode berikutnya.

\section{B. TINJAUAN PUSTAKA}

Moving Average adalah salah satu indikator teknis yang dikenal luas digunakan untuk memprediksi data masa depan dalam analisis deret waktu. Selama pengembangannya, banyak variasi dan implementasi telah dilakukan oleh para peneliti.Salah satu variasi yang banyak digunakan adalah Exponential Moving Average (EMA).Pada dasarnya, EMA adalah peningkatan dari Weighted Moving Average (WMA) yang memberikan bobot khusus untuk data yang lebih baru daripada data yang lebih lama, yang tidak dapat ditemukan dalam metode Simple Moving Average (SMA). (Seng Hansun, 2014: 22). Metode
Moving Average yang kita bahas pada makalah ini ada tiga macam yaitu:

\section{Simple Moving Average (SMA)}

Simple Moving Average atau juga disingkat SMA adalah Moving Average paling sederhana dan tidak menggunakan pembobotan dalam perhitunganperamalan. Meskipun sederhana, SMA cukup efektif dalam menentukan trend yang sedang terjadi di market. Cara pembacaannyapun sederhana.(Marcelina,2011:2 dalam Hari Utari, et al, 2016: 2)

Simple Moving Average (SMA) dihitung dengan cara mengambil nilai rata-rata dari harga suatu penjualan pada rentang waktu tertentu ke belakang. (Hendarto, 2005: 92 dalam Johanes F.A., 2015: 20)

Formula yang dapat diterapkan dalam metode Simple Moving Average antara lain:

$\mathrm{SMA}=\frac{X_{t}+X_{t-1}+X_{t-2}+\ldots+X_{t-n+1}}{n}$

Keterangan:

$$
\begin{aligned}
& \mathrm{X}_{t}=\text { data aktual pada periode }(\mathrm{t}) \text { tertentu } \\
& \mathrm{n}=\text { banyak data } \\
& \text { (Prayadi Sulistyanto, Oyas Wahyunggoro, } \\
& \text { Adha Imam Cahyadi, 2015: } 25 \text { ) }
\end{aligned}
$$

\section{Weighted Moving Average (WMA)}

Weighted Moving Average (WMA) adalah bentuk peningkatan Simple Moving Average (SMA).itu memberikan bobot lebih besar untuk data yang lebih baru daripada yang lebih lama. Faktor bobot dihitung dari jumlah hari yang digunakan dalam data deret waktu, juga dikenal sebagai jumlah digit. (Seng Hansun, 2014: 23). Formula yang dapat diterapkan pada Weighted Moving Average antara lain:

$\mathrm{WMA}=\frac{\sum\left(X_{t} \times W\right)}{\sum W}$

Keterangan:

$\mathrm{X}_{t}=$ data aktual pada periode $(\mathrm{t})$ tertentu

$\mathrm{W}=$ bobot

(Prayadi Sulistyanto, Oyas Wahyunggoro, Adha Imam Cahyadi, 2015: 25)

\section{Exponential Moving Average (EMA)}

Exponential Moving Average (EMA)adalah jenis WMA yang menetapkan faktor bobot untuk setiap nilai dalam seri data sesuai dengan usianya. Seperti 
WMA, dalam EMA data terbaru mendapatkan bobot terbesar dan setiap nilai data mendapat bobot lebih kecil saat kita kembali secara kronologis, tetapi tidak seperti WMA, dalam EMA bobot untuk setiap titik data lama menurun secara eksponensial, sehingga tidak pernah mencapai nol. (Seng Hansun, 2014: 23)

Formula yang dapat diterapkan pada Exponential Moving Average antara lain:

$\mathrm{EMA}=\left(\frac{2}{t+1} \times\left(X_{t}-F_{t-1}\right)\right)+F_{t-1}$

Keterangan:

$t=$ periode

$X_{t}=$ data aktual pada periode $(\mathrm{t})$ tertentu

$F_{t-1}=$ nilai EMA sebelumnya

(Prayadi Sulistyanto, Oyas Wahyunggoro, Adha Imam Cahyadi, 2015: 25)

Untuk perhitungan pada data pertama kita menggunakan metode SMA karena nilai EMA sebelumnya belum ada, lalu data selanjutnya menggunakan metode EMA di atas.(Prayadi Sulistyanto, Oyas Wahyunggoro, Adha Imam Cahyadi, 2015: 27)

\section{Naive Method}

Naive Method merupakan metode peramalan yang sangat sederhana, dimana metode ini sering digunakan sebagai pembanding karena kemudahan dalam memperoleh hasil peramalan.(Hanke, 2003 dalam Theresia O.R.P, Rossi S.W, 2014: 404). Formula yang dapat diterapkan pada metode Naive antara lain:

$$
\text { Naive Method }=X_{t-1}(4)
$$

Dimana $X_{t}=$ data aktual pada periode t. Jadi, nilai peramalan untuk data selanjutnya sama dengan data aktual sebelumnya. (Lim Sanny, Haryadi Sarjono, 2013: 207)

\section{METODE PENELITIAN}

Teknik peramalan yang dilakukan menggunakan Moving Averageini bersifat kuantitatif yaitu menurut Makridakis et al(1991:8 dalam Haryanto Tanuwijaya, 2010: 3) peramalan kuantitatif dapat dilakukan apabila terdapat 3 (tiga) kondisi, yaitu: (1) tersedia informasi masa lalu, (2) informasi tersebut dapat dikuantitatifkan dalam bentuk data numerik, dan (3) dapat diasumsikan bahwa beberapa aspek pola masa lalu akan terus berlanjut di masa mendatang. Menurut Makridakisetal (1991:96 dalam Haryanto
Tanuwijaya, 2010: 3) metode peramalan yang dianggap tepat untuk data berpola stasioner seperti metode rata-rata bergerak (moving average) dan penghalusan eksponensial tunggal (single exponential smoothing).

Peramalan dengan metode yang bersifat kuantitatif memanfaatkan berbagai model matematis atau statistik serta data masa lalu dan atau variabelvariabel kausal untuk meramalkan nilai di masa mendatang.(Amira Herwindyani Hutasuhut, Wiwik Anggraeni, Raras Tyasnurita, 2014: 170). Data yang akan kami gunakan yaitu data jumlah kemiskinan penduduk (jiwa) provinsi NTB dari tahun 2002 sampai dengan tahun 2018 pada Tabel 1 berikut.

Tabel 1. Jumlah Penduduk Miskin (Jiwa) Provinsi NTB

\begin{tabular}{cc}
\hline Tahun & Jumlah \\
\hline 2002 & 1.145 .081 \\
\hline 2003 & 1.054 .740 \\
\hline 2004 & 1.031 .605 \\
\hline 2005 & 1.136 .524 \\
\hline 2006 & 1.156 .144 \\
\hline 2007 & 1.118 .452 \\
\hline 2008 & 1.080 .613 \\
\hline 2009 & 1.050 .948 \\
\hline 2010 & 1.009 .352 \\
\hline 2011 & 900.573 \\
\hline 2012 & 862.516 \\
\hline 2013 & 843.660 \\
\hline 2014 & 820.818 \\
\hline 2015 & 823.886 \\
\hline 2016 & 804.450 \\
\hline 2017 & 793.776 \\
\hline 2018 & 737.460 \\
\hline$(S u m b$ & \\
\hline
\end{tabular}

(Sumber: https://ntb.bps.go.id)

Tujuan dilakukannya penelitian ini adalah untuk menghitung peramalan dari data jumlah kemiskinan penduduk (jiwa) provinsi NTB dari tahun 2002 sampai dengan tahun 2018 pada Tabel 1 di atas. Peramalan (forecasting) adalah kegiatan mengestimasi apa yang akan terjadi pada masa yang akan datang. Peramalan diperlukan karena adanya kesenjangan waktu (timelag) antara kesadaran dibutuhkannya suatu kebijakan baru dengan waktu pelaksanaan kebijakan tersebut. Jika perbedaan waktu tersebut panjang, maka peran peramalan begitu penting dan sangat dibutuhkan terutama dalam penentuan waktu kapan akan terjadinya sesuatu, sehingga dapat dipersiapkan tindakan yang 
perlu dilakukan. (Sudarsono, 2016 dalam Lalu Sucipto, Syaharuddin, 2018: 114)

Metode perhitungan peramalan yang akan kami gunakan dalam penelitian ini adalah metode Naivedan Moving Average yang terbagi menjadi tiga jenis indikator yaitu Simple Moving Average, Weighted Moving Average dan Exponential Moving Average.Dalam penelitian ini, kami akan menggunakan metode Moving Average2 (MA2)dan metodeMoving Average3(MA3) untuk ketiga jenis indikator pada metode Moving Average di atas.Metode Moving Average2 (MA2) adalah metode peramalan dengan menggunakan data dari dua periode sebelumnya, sedangkan Moving Average3 (MA3)adalah metode peramalan dengan menggunakan data dari tiga periode sebelumnya.

Parameter keakuratan data dalam mencari error yang akan kami gunakan adalahMean Absolute Deviation(MAD),Mean Square Error(MSE),Root mean Squared Error (RMSE) danMean Absolute Percentage Error (MAPE). Formula yang dapat diterapkan dalam empat error tersebut antara lain:

$$
\begin{aligned}
& M A D=\frac{\sum_{t=1}^{n}\left|X_{t}-F_{t}\right|}{n} \\
& M S E=\frac{\sum_{t=1}^{n}\left(X_{t}-F_{t}\right)^{2}}{n}
\end{aligned}
$$

RMSE $=\sqrt{\frac{\sum_{i=1}^{n}\left(X_{t}-F_{t}\right)^{2}}{n}}$

$M A P E=\left(\frac{1}{n}\right) \sum_{t=1}^{n}\left|\frac{X_{t}-F_{t}}{X_{t}}\right|$

Keterangan :

$X_{t}=$ data aktual pada periode $(\mathrm{t})$ tertentu

$F_{t}=$ nilai peramalan pada periode $(\mathrm{t})$ tertentu

$n=$ jumlah data

Adapun Algoritma yang digunakan dalam peramalan ini adalah sebagai berikut.

1. Mengumpulkan dan tabulasi data

2. Memilih metode yang digunakan yang terdiri dari Simple Moving Average, Weighted Moving Average, Exponential Moving Average, dan metode Naive

3. Meramalkan data tahun 2019 dengan metode peramalan yang dipilih

4. Menentukan parameter error yakni MAD, MSE, RMSE dan MAPE
5. Melakukan interpretasi hasil peramalan

6. Menarik kesimpulan

\section{HASIL DAN PEMBAHASAN}

Menghitung peramalan (forecast)danerror dari data jumlah penduduk miskin tahun 2002 sampai dengan tahun 2018 dengan menggunakan metode Simple Moving Average, Weighted Moving Average dan Exponential Moving Average.

\section{Simple Moving Average (SMA)}

a. Menghitung nilai SMA untuk Moving Average 2 (MA2) dan Moving Average 3(MA3) dengan menggunakan rumus yang telah ditentukan. Maka akan muncul hasil dari perhitungan SMA MA2 dan MA3 seperti pada Tabel 2 dibawah ini.

Tabel 2. Hasil Prediksi SMA MA2 dan MA3

\begin{tabular}{cccc}
\hline Tahun $(\mathbf{t})$ & Data Aktual $\left(\mathbf{X}_{\mathbf{t}}\right)$ & $\mathbf{M A 2}\left(\mathbf{F}_{\mathbf{t}}\right)$ & MA3 $\left(\mathbf{F}_{\mathbf{t}}\right)$ \\
\hline 2002 & 1.145 .081 & 0 & 0 \\
\hline 2003 & 1.054 .740 & 0 & 0 \\
\hline 2004 & 1.031 .605 & 1.099 .911 & 0 \\
\hline 2005 & 1.136 .524 & 1.043 .173 & 1.077 .142 \\
\hline 2006 & 1.156 .144 & 1.084 .065 & 1.074 .290 \\
\hline 2007 & 1.118 .452 & 1.146 .334 & 1.108 .091 \\
\hline 2008 & 1.080 .613 & 1.137 .298 & 1.137 .040 \\
\hline 2009 & 1.050 .948 & 1.099 .533 & 1.118 .403 \\
\hline 2010 & 1.009 .352 & 1.065 .781 & 1.083 .338 \\
\hline 2011 & 900.573 & 1.030 .150 & 1.046 .971 \\
\hline 2012 & 862.516 & 954.963 & 986.958 \\
\hline 2013 & 843.660 & 881.545 & 924.147 \\
\hline 2014 & 820.818 & 853.088 & 868.916 \\
\hline 2015 & 823.886 & 832.239 & 842.331 \\
\hline 2016 & 804.450 & 822.352 & 829.455 \\
\hline 2017 & 793.776 & 814.168 & 816.385 \\
\hline 2018 & 737,460 & 799.113 & 807.371 \\
\hline 2019 & - & 765.618 & 778.562 \\
\hline
\end{tabular}

b. Berdasarkan prediksi SMA MA2 pada Tabel 2 diatas diperoleh nilaierror untuk MAD sebesar 54.919,633; MSE sebesar 4.035.409.695;RMSE sebesar63.524,875; dan MAPE sebesar 0,058.

c. Berdasarkan prediksi SMA MA3 pada Tabel 2 diatas diperoleh nilai error untuk MAD sebesar63.204,238; MSE sebesar 5.401.113.771; RMSE sebesar 73.492,270; dan MAPE sebesar 0,069.

d. Langkah terakhir yaitu membuat grafik dari data $\mathrm{X}_{\mathrm{t}}$ dan $\mathrm{F}_{\mathrm{t}}$ dengan memblok kedua data dan mengklik "line" pada menu charts maka akan terlihat hasil dari grafik SMA MA2 dan MA3 seperti pada Gambar 1untuk SMA MA2 dan Gambar 2 untuk SMA MA3 di bawah ini. 


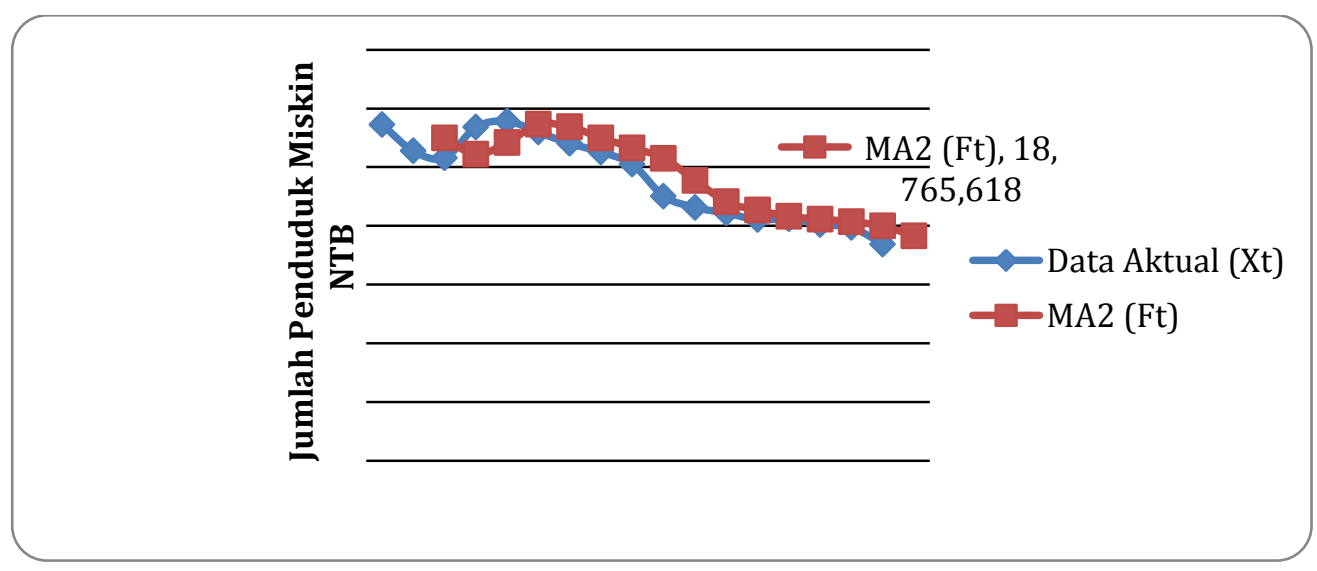

Gambar 1. Hasil Simulasi untuk SMA MA2

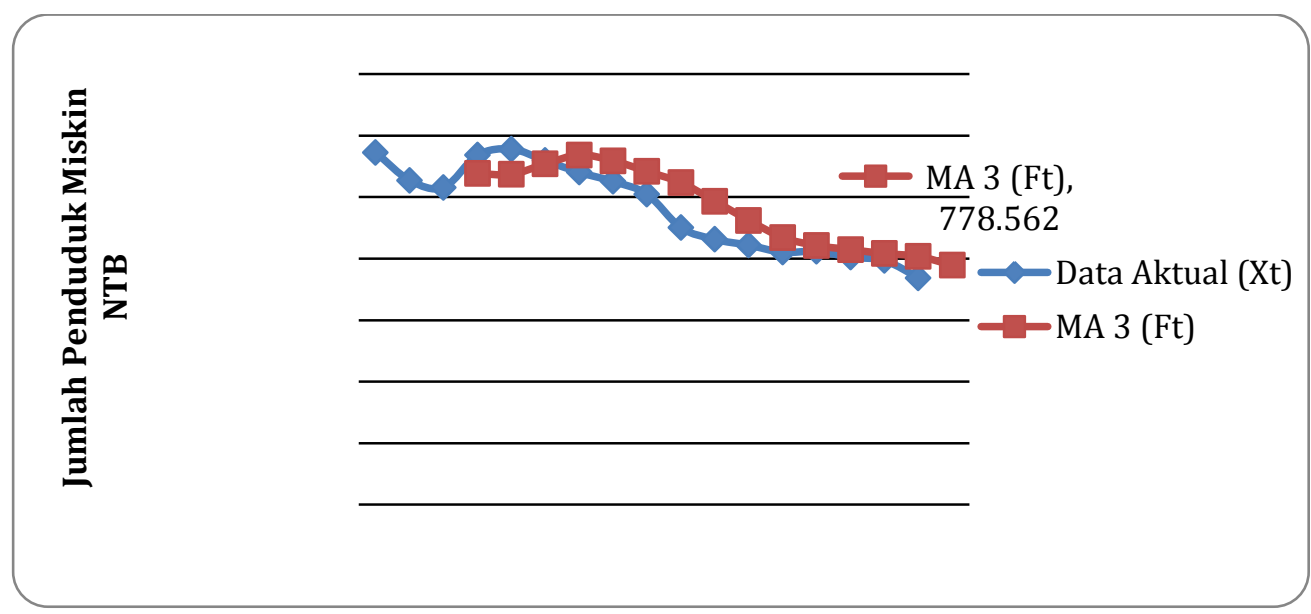

Gambar 2. Hasil Simulasi untuk SMA MA3

\section{Weighted Moving Average (WMA)}

a. Menghitung nilai WMAMoving Average 2 (MA2) danMoving Average 3(MA3) dengan bobot 0,6dan 0,4 untuk WMA MA2 dan bobot 0,2, 0,3 dan 0,5 untuk WMA MA3. Sehingga menghasilkan nilai Weighted Moving Average seperti pada Tabel3 dibawah ini.

Tabel 3. Hasil Prediksi Metode WMA MA2 dan WMA MA3

\begin{tabular}{cccc}
\hline Tahun $(\mathbf{t})$ & Data Aktual $\left(\mathbf{X}_{\mathbf{t}}\right)$ & MA2 $\left(\mathbf{F}_{\mathbf{t}}\right)$ & MA3 $\left(\mathbf{F}_{\mathbf{t}}\right)$ \\
\hline 2002 & 1.145 .081 & 0 & 0 \\
\hline 2003 & 1.054 .740 & 0 & 0 \\
\hline 2004 & 1.031 .605 & 1.090 .876 & 0 \\
\hline 2005 & 1.136 .524 & 1.040 .859 & 1.061 .241 \\
\hline 2006 & 1.156 .144 & 1.094 .556 & 1.088 .692 \\
\hline 2007 & 1.118 .452 & 1.148 .296 & 1.125 .350 \\
\hline 2008 & 1.080 .613 & 1.133 .529 & 1.133 .374 \\
\hline 2009 & 1.050 .948 & 1.095 .749 & 1.107 .071 \\
\hline 2010 & 1.009 .352 & 1.062 .814 & 1.073 .348 \\
\hline 2011 & 900.573 & 1.025 .990 & 1.036 .083 \\
\hline 2012 & 862.516 & 944.085 & 963.282 \\
\hline 2013 & 843.660 & 877.739 & 903.300 \\
\hline 2014 & 820.818 & 851.202 & 860.699 \\
\hline
\end{tabular}

\begin{tabular}{cccc}
\hline 2015 & 823.886 & 829.955 & 836.010 \\
\hline 2016 & 804.450 & 822.659 & 826.920 \\
\hline 2017 & 793.776 & 812.224 & 813.554 \\
\hline 2018 & 737.460 & 798.046 & 803.000 \\
\hline 2019 & - & 759.986 & 767.753 \\
\hline
\end{tabular}

b. Berdasarkan prediksi WMA MA2 pada Tabel 3 diatas diperoleh error untuk MAD sebesar 51.487,147; MSE sebesar 3.590.722.347; RMSE sebesar 59.922,636; dan MAPE sebesar0,054.Sedangkan berdasarkan prediksi WMA MA3 pada Tabel 3 diatas diperoleherror untuk MAD sebesar 51.881,653; MSE sebesar 3.953.121.699; RMSE sebesar 62.873,855; dan MAPE sebesar 0,056 .

c. Lalu menggambar grafik WMA MA2 dan MA3 dengan langkah-langkah yang sama seperti pada pembuatan grafik SMA. Maka akan muncul grafik WMA MA2 dan MA3 seperti pada Gambar 3 untuk MA2 dan Gambar 4 untuk MA3 dibawah ini. 


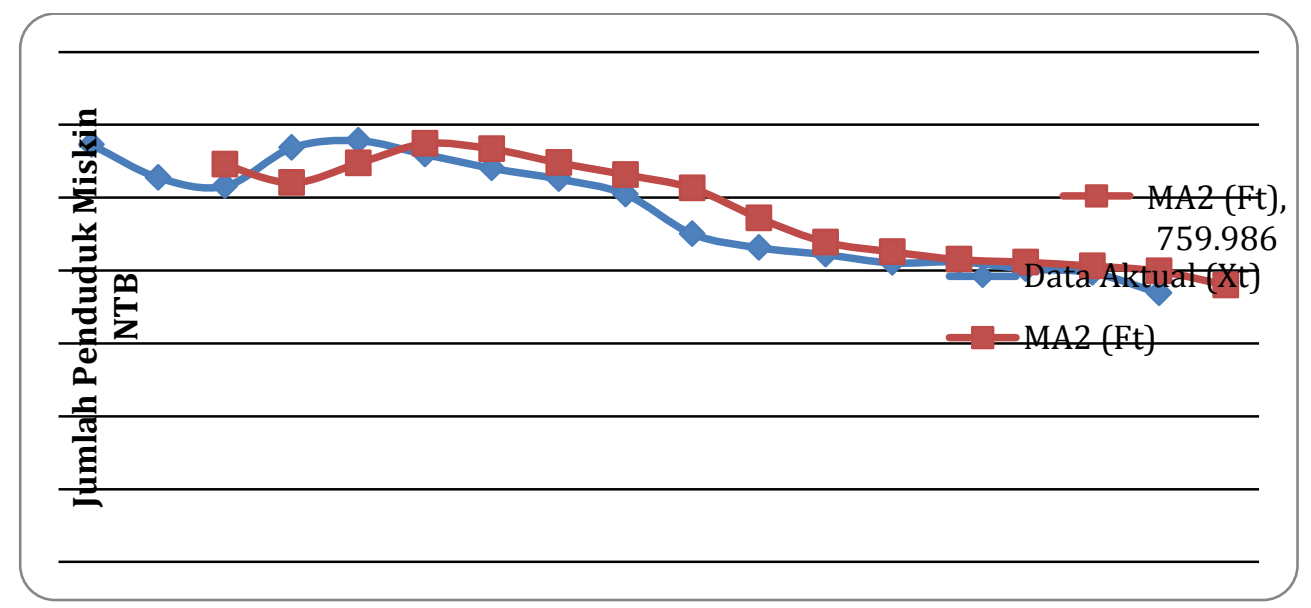

Gambar 3.Hasil Simulasi untuk WMA MA2

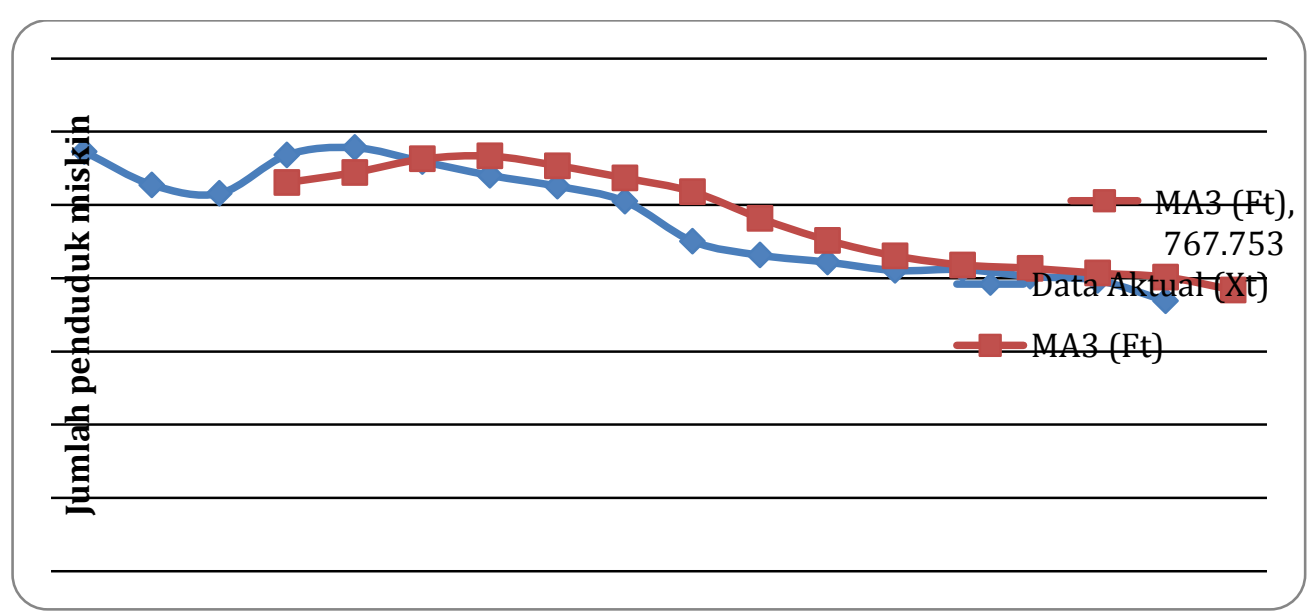

Gambar 4. Hasil Simulasi untuk WMA MA3

\section{Exponential Moving Average (EMA)}

a. Menghitung nilai EMA pertama dengan rumus SMA karena nilai EMA sebelumnya belum ada. Lalu menghitung nilai EMA MA2 dan MA3 selanjutnya dengan menggunakan rumus EMA yang telah diketahui, sehingga akan mengahasilkan EMA MA2 dan MA3 seperti pada Tabel4 di bawah ini.

Tabel 4. Hasil Prediksi Metode EMA MA2 dan MA3

\begin{tabular}{cccc}
\hline Tahun $(\mathbf{t})$ & Data Aktual $\left(\mathbf{X}_{\mathbf{t}}\right)$ & $\mathbf{M A 2}\left(\mathbf{F}_{\mathbf{t}}\right)$ & $\mathbf{M A 3}\left(\mathbf{F}_{\mathbf{t}}\right)$ \\
\hline 2002 & 1.145 .081 & 0 & 0 \\
\hline 2003 & 1.054 .740 & 0 & 0 \\
\hline 2004 & 1.031 .605 & 1.099 .911 & 0 \\
\hline 2005 & 1.136 .524 & 1.054 .374 & 1.077 .142 \\
\hline 2006 & 1.156 .144 & 1.109 .141 & 1.106 .833 \\
\hline 2007 & 1.118 .452 & 1.140 .476 & 1.131 .489 \\
\hline 2008 & 1.080 .613 & 1.125 .793 & 1.124 .970 \\
\hline 2009 & 1.050 .948 & 1.095 .673 & 1.102 .792 \\
\hline 2010 & 1.009 .352 & 1.065 .856 & 1.076 .870 \\
\hline 2011 & 900.573 & 1.028 .187 & 1.043 .111 \\
\hline 2012 & 862.516 & 943.111 & 971.842 \\
\hline 2013 & 843.660 & 889.381 & 917.179 \\
\hline 2014 & 820.818 & 858.900 & 880.419 \\
\hline
\end{tabular}

\begin{tabular}{cccc}
\hline 2015 & 823.886 & 833.512 & 850.619 \\
\hline 2016 & 804.450 & 827.095 & 837.252 \\
\hline 2017 & 793.776 & 811.998 & 820.851 \\
\hline 2018 & 737.460 & 799.850 & 807.314 \\
\hline 2019 & - & 758.257 & 772.387 \\
\hline
\end{tabular}

b. Berdasarkan prediksi EMA MA2 pada Tabel 4 di atas diperoleh error untuk MAD sebesar 51.385,914; MSE sebesar 3.499.639.901; RMSE sebesar 59.157,754; dan MAPE sebesar 0,055.Sedangkan berdasarkan prediksi EMA MA3 pada Tabel 4 diatas diperoleh error untuk MAD sebesar 59.064,029; MSE sebesar 4.569.395.465; RMSE sebesar 67.597,311; dan MAPE sebesar 0,065.

c. Menggambar grafik EMA MA2 dan MA3 dengan langkah-langkah yang sama seperti pada langkah penggambaran grafik untuk SimpleMoving Averagedan Weighted Moving Average diatas, sehingga akan muncul grafik seperti pada Gambar 5 untuk MA2 dan Gambar 6 untuk MA3 dibawah ini. 


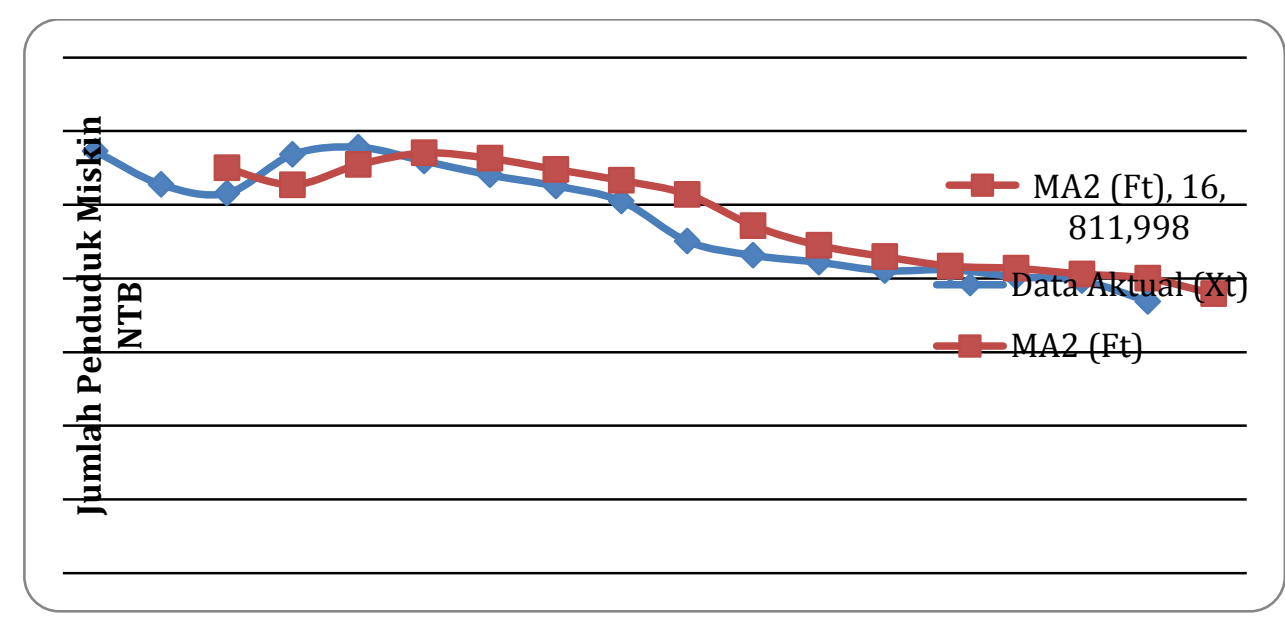

Gambar 5. Hasil Simulasi untuk EMA MA2

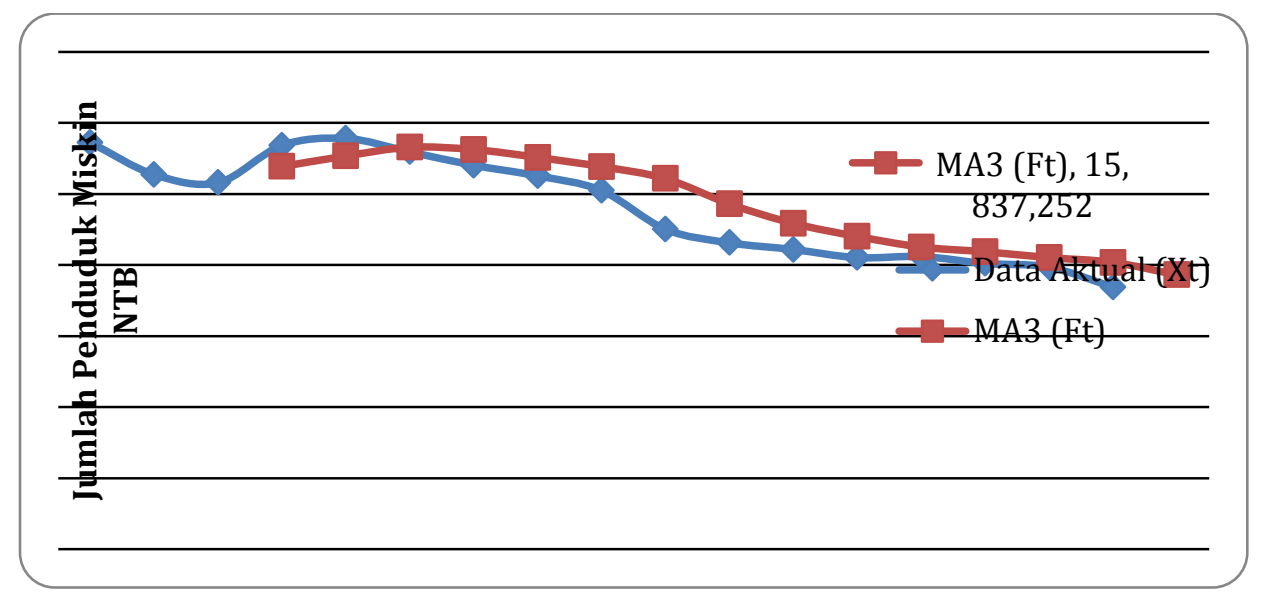

Gambar 6. Hasil untuk EMA MA3

\section{Metode Naive}

a. Menghitung peramalan menggunakan metode Naive dengan memasukkan rumus metode Naive yaitu $X_{t-1}$, sehingga akan diperoleh hasil seperti pada Tabel5 dibawah ini.

Tabel 5. Hasil Prediksi Metode Naive

\begin{tabular}{ccc} 
Tahun $(\mathbf{t})$ & Data Aktual $\left(\mathbf{X}_{\mathbf{t}}\right)$ & Metode Naive $\left(\mathbf{F}_{\mathbf{t}}\right)$ \\
\hline 2002 & 1.145 .081 & 0 \\
\hline 2003 & 1.054 .740 & 1.145 .081 \\
\hline 2004 & 1.031 .605 & 1.054 .740 \\
\hline 2005 & 1.136 .524 & 1.031 .605 \\
\hline 2006 & 1.156 .144 & 1.136 .524 \\
\hline 2007 & 1.118 .452 & 1.156 .144 \\
\hline 2008 & 1.080 .613 & 1.118 .452 \\
\hline 2009 & 1.050 .948 & 1.080 .613 \\
\hline 2010 & 1.009 .352 & 1.050 .948 \\
\hline 2011 & 900.573 & 1.009 .352 \\
\hline 2012 & 862.516 & 900.573 \\
\hline 2013 & 843.660 & 862.516
\end{tabular}

\begin{tabular}{lcc}
\hline 2014 & 820.818 & 843.660 \\
\hline 2015 & 823.886 & 820.818 \\
\hline 2016 & 804.450 & 823.886 \\
\hline 2017 & 793.776 & 804.450 \\
\hline 2018 & 737.460 & 793.776 \\
\hline 2019 & - & 737.460 \\
\hline
\end{tabular}

b. Berdasarkan prediksi perhitungan Naive pada Tabel 5 diatas diperoleh nilai error MAD sebesar 41.427,188; MSE sebesar 2.711.468.146; RMSE 52.071,760; dan MAPE sebesar 0,043.

c. Menggambar grafik metode Naive menggunakan langkah-langkah yang sama dengan langkah-langkah penggambaran grafik sebelumnya. Maka akan muncul grafik seperti pada Gambar7 dibawah ini. 


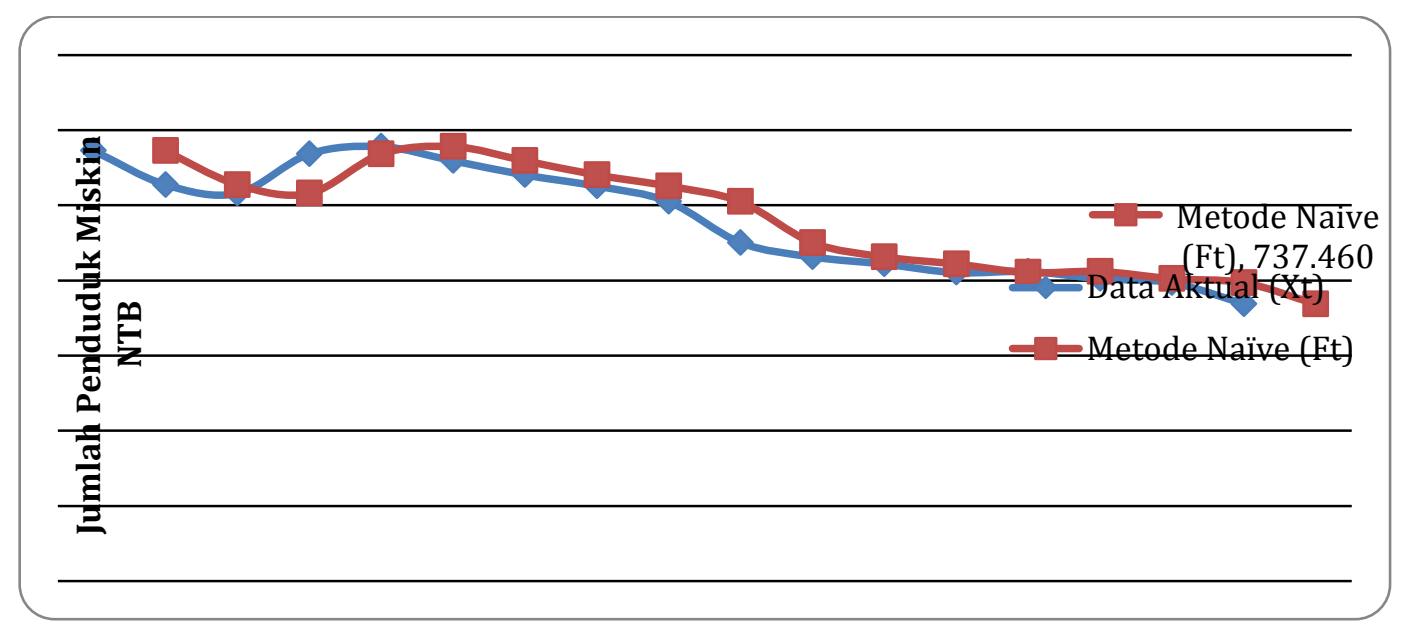

Gambar 7. Hasil Simulasi untuk Metode Naive

Berdasarkan hasil simulasi peramalan Moving Average (EMA) dan juga dengan menggunakan metode Moving Averagedengan tiga menggunakan metode Naive diatas, dapat kami indikator yaitu Simple Moving Average (SMA), rangkum dalam Tabel 6 dibawah ini. Weighted Moving Average (WMA), dan Exponential

Tabel 6. Hasil Keseluruhan Data Yang Dicari

\begin{tabular}{cccccc}
\hline \multirow{2}{*}{ Metode } & \multirow{2}{*}{ Prediksi } & \multicolumn{5}{c}{ Error } \\
\cline { 3 - 6 } & & MAD & MSE & RMSE & MAPE \\
\hline SMA MA2 & 765.618 & $54.919,633$ & 4.035 .409 .695 & $63.524,875$ & 0,058 \\
\hline SMA MA3 & 778.562 & $63.204,238$ & 5.401 .113 .771 & $73.492,270$ & 0,069 \\
\hline WMA MA2 & 759.986 & $51.487,147$ & 3.590 .722 .347 & $59.922,636$ & 0,054 \\
\hline WMA MA3 & 767.753 & $51.881,653$ & 3.953 .121 .699 & $62.873,855$ & 0,056 \\
\hline EMA MA2 & 758.257 & $51.385,914$ & 3.499 .639 .901 & $59.157,754$ & 0,055 \\
\hline EMA MA3 & 772.387 & $59.064,029$ & 4.569 .396 .465 & $67.597,311$ & 0,065 \\
\hline Metode Naive & 737.460 & $41.427,188$ & 2.711 .468 .146 & $52.071,760$ & 0,043 \\
\hline
\end{tabular}

\section{E. SIMPULAN DAN SARAN}

Berdasarkan hasil simulasi diatas, kami memperoleh kesimpulan bahwa metode terbaik dari metode-metode diatas yang digunakan dalam prediksi data jumlah kemiskinan penduduk provinsi NTB tahun 2019 adalah metode Naive dengan hasil prediksi tahun 2019 sebesar 737.460 dengan MAD, MSE, RMSE dan MAPE berturut turut sebesar 41.427,188; 2.711.468.146; 52.071,760 dan 0,043.Sehingga, diperoleh pada metode forecasting ini sebuah nilai peramalan yang paling akurat dengan menggunakan metode Naive.

Selanjutnya, dari penelitian yang telah kami lakukan ada beberapa saran yang kami berikan yaitu dalam menghitung peramalan(forecast) atau memprediksikan suatu hal pada ekonomi, statistik dan lain sebagainya, akan lebih baik apabila mencoba berbagai macam metode dan menggunakan data-data yang lebih banyak lagi untuk menemukan hasil yang paling akurat dari metode-metode yang dilakukan.

\section{REFERENSI}

Andry, Johanes, Fernandes. (2015). Analisa Perbandingan Penerapan E-Commerce Terhadap Transaksi Penjualan Konvensional Menggunakan Metode Simple Moving Average. Jurnal Teknologi Informasi, 11(1), 19-26.

Anisya., \& Yunita, Wandyra. (2016). Rekayasa Perangkat Lunak Pengendalian Inventori Menggunakan metode SMA (Single Moving Average) Berbasis AJAX (Asynchronous Javascript and XML) (Studi Kasus: PTP Nusantara VI. Jurnal Teknolf, 4(2), 11-17.

Hansun, Seng. (2014). A Novel Research of New Moving Average Method in Time Series Analysis.International Journal of New Media Technology, 1(1), 22-26.

Hansun, Seng. (2015). Implementasi Simple Moving Average dan Exponential Moving Average dalam Menentukan Tren Harga Saham Perusahaan. Ultimatics, 7(2), 113-124. Doi: 10.31937/ti.v7i2.354

Hutasuhut, Amira, Herwindyani., Wiwik, Anggraeni., \& Raras, Tyasnurita. (2014). Pembuatan Aplikasi Pendukung Keputusan untuk Peramalan Persediaaan Bahan Baku Produksi Plastic Blowing dan Inject Menggunakan Metode ARIMA (Autoregressive Integrated Moving Average) di CV. Asia. Jurnal Teknik ITS, 3(2), A169-A174. 
Nurlifa, Alfian \& Sri, Kusumadewi. (2017). Sistem Peramalan Jumlah Penjualan Menggunakan Metode Moving Average Pada Rumah Jilbab Zaky. INOVTEK Polbeng-Seri Informatika, 2(1), 18-25.

Pasaribu, Theresia O.R., \& Rossi, Septy Wahyuni. (2014). Penentuan metode peramalan sebagai dasar penentuan tingkat kebutuhan persediaan pengaman produk karet remah sir 20. Prosiding Seminar Ilmiah Nasional Komputer dan Sistem Intelijen (KOMMIT), 8, 402-408.

Rozi, Fahrur \& Farid Sukmana. (2016). Penggunaan Moving Average Dengan Metode Hybrid Artificial Neural Network Dan Fuzzy Inference System Untuk Prediksi Cuaca. JIPI (Jurnal Ilmiah Penelitian dan Pembelajaran Informatika), 1(2), 38-42.

Sanny, Lim., \& Haryadi, Sarjono. (2013). Peramalan Jumlah Siswa/I Sekolah Menengah Atas Swasta Menggunakan Enam Metode Forecasting. Forum Ilmiah, 10(2), 198-208.

Sucipto, Lalu., \& Syaharudin, Syaharudin. (2018).Konstruksi Forecasting System Multi-Model untuk pemodelan matematika pada peramalan Indeks Pembangunan Manusia Provinsi Nusa Tenggara Barat. Jurnal Ilmiah Teknologi Sistem Informasi, 4 (2), 114123.

Sulistyanto, Prayadi,. Oyas, Wahyunggoro,.\& Adha, Imam, Cahyadi. (2015). Pengolahan Isyarat Load Cell Sen128a3b Menggunakan Metode Moving Average. Stmik Amikom Yogyakarta. 2 (1), 25-30

Tanuwijaya, Haryanto. (2010). Penerapan metode winter's exponential smooting dan single moving average dalam sistem informasi pengadaan obat rumah sakit. Prosiding Seminar Nasional Manajemen Teknologi XI, 12, 1-10.

Utari,Hari., Mesran., \& Natalia, Silalahi. (2016). Perancangan Aplikasi Peramalan Permintaan Kebutuhan Tenaga Kerja Pada Perusahaan Outsourcing Menggunakan Algoritma Simple Moving Average.Jurnal Times, 5(2), 1-5. 